\title{
THE COMPLEX OF CHOR BAKR IN BUKHARA: AN ARCHAEOLOGICAL AND ARCHITECTURAL STUDY
}

\author{
Roshdy, M. \\ Islamic dept., Faculty of Archaeology, Cairo Univ \\ E-mail: mahmoud_roshdy50@yahoo.com
}

\begin{abstract}
The architectural complexes in Central Asia received great attention by the sultans and princes who significantly contributed to building them, including mosques, madāris, and khanqahs. Bukhara held many of the complexes, indicating the prosperous architectural activity that reflected the architectural creations and traditions of the city. In addition, it showed the skills of architects and artists in giving cohesion to the environment in Central Asia, as well as the variety of architectural and decorative units. Therefore, the present study of the Complex of Chor Bakr aims to define the relationship between the buildings and the political, scientific, and artistic conditions and to recognize the architectural features of the buildings in Bukhara during the Shaibanid era.
\end{abstract}

Keywords: Bukhara, Mosque, Madrasa, Khanqah, Iwan, Mihrab

\section{Introduction}

Chor Bakr Complex, fig. (1), which comprises a mosque and a Madrasa, was established in the village of Sumitkhan [1]; about 5 kilometers to the west of Bukhara [2] by Khawaja Ismail, Sheikh of "Khawaja Can". It was called "the Tomb of Chor Bakr" in the memory of the four early imams, namely Bakr Saad [3], his son Imam Bakr Ahmed, Imam Bakr

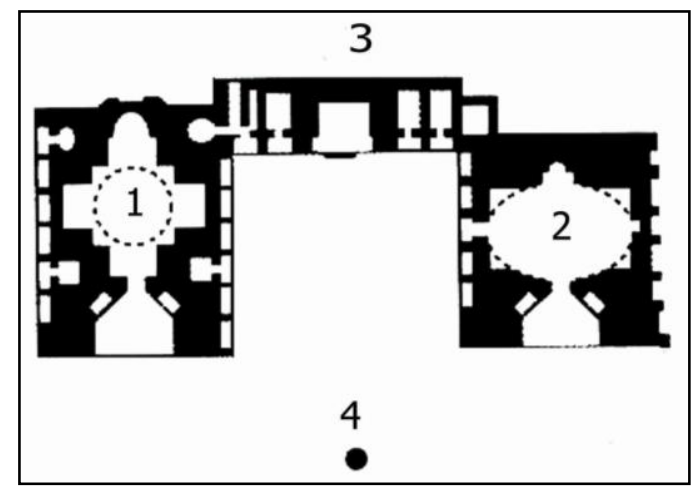

Figure (1) Shows the plan of the complex of Chor Bakr in Bukhara
Turhan, and Imam Bakr Ishaq [4]. The complex dates back to (967-977 AH / 1559-1569 A.D). It was reconstructed during the reign of Abdullah Khan [5]. The mosque, the minaret, and the Khanaqah of Sufism were installed on a berth in the form of an open Russian letter (П) on the eastern side, pl. (1).

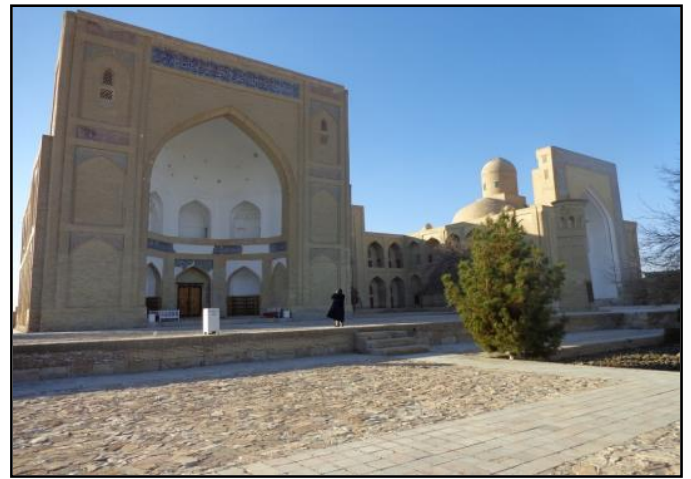

Plate (1) Shows general view of the complex 


\section{The Analytical Study}

Each section of the four tombs is enclosed by walls with domes where the family members of the four imams were buried. The tombs consist of the main façade with the Iwan. Behind the façade,

\subsection{The mosque}

The mosque was modeled after the layout of closed mosques, pl. (2), with no courtyards, pl. (3). It is a part of Chor Bakr complex that includes a khanqah and a madrasa, as well. Moving in from the door in the northeastern façade, the mosque consists of a central area covered with a large dome based on Turkish triangles, $\mathrm{pl}_{\mathrm{s} .}(4,5)$ set with four Iwans with pointed arches. In the southwestern part, there is an iwan set with a projecting niche crowned by a pointed arch. It is made of bricks with a layer of plaster and it has a rectangular projection. The area of the mosque was increased by four iwans in order to hold the largest number of

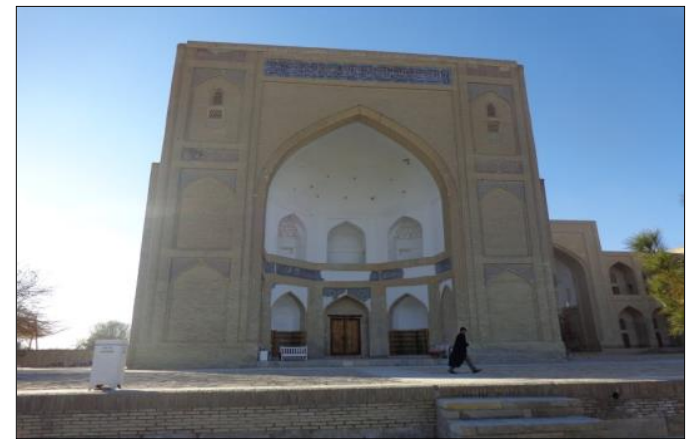

Plate (2) Shows the main façade of the mosque of Chor Bakr in Bukhara

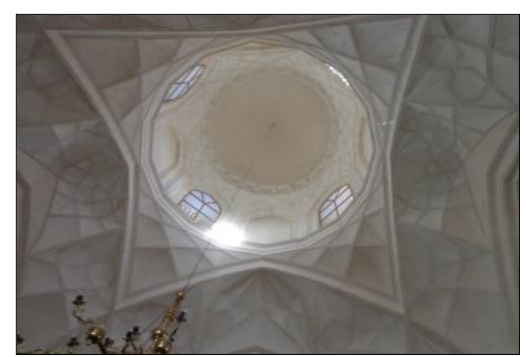

Plate (4) Shows interior of the dome that covers the mosque

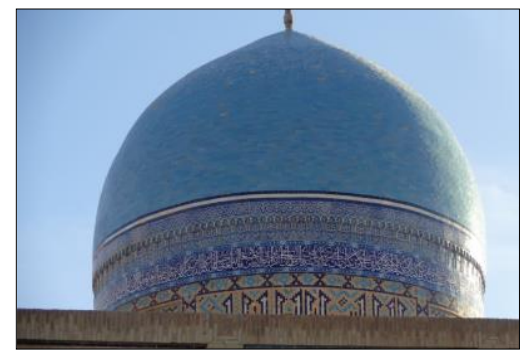

Plate (5) Shows the helmet of the dome there are the cells of the Guivari sheiks enclosed by a wall, where family members are buried [6]. Furthermore, the mosque and the khanqah comprise a mihrab.

worshippers [7]. The northeastern façade is a large memorial one. Its center is a pentacle niche with a pointed arch consisting of two levels. While the lower level encompasses the door opening with wooden shutters, the upper one has three windows. Near the eastern corner, there is a nine-meter cylindrical minaret; about 15 $\mathrm{m}$ away from the mosque. It is large in the bottom and the top, but it is narrow in the middle. Additionally, a pavilion crowns the upper part of the minaret covered with a shallow dome, pl. (6). This minaret dates back to the late $13^{\text {th }} \mathrm{AH} / 19^{\text {th }} \mathrm{AD}$ (early $14^{\text {th }} \mathrm{AH} / 20^{\text {th }} \mathrm{AD}$ ) century [8].

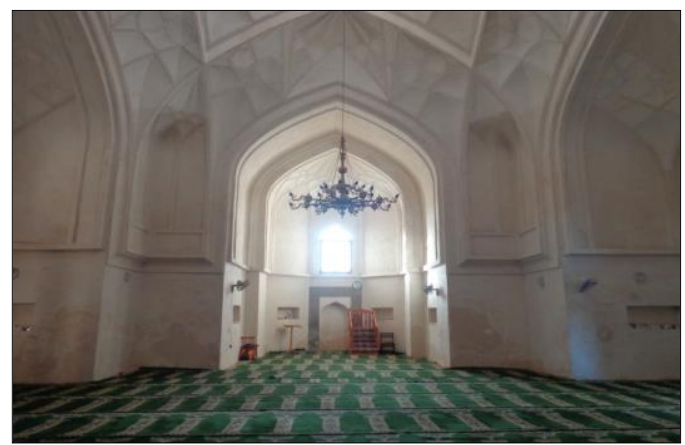

Plate (3) Shows the mosque of Chor Bakr from inside in Bukhara

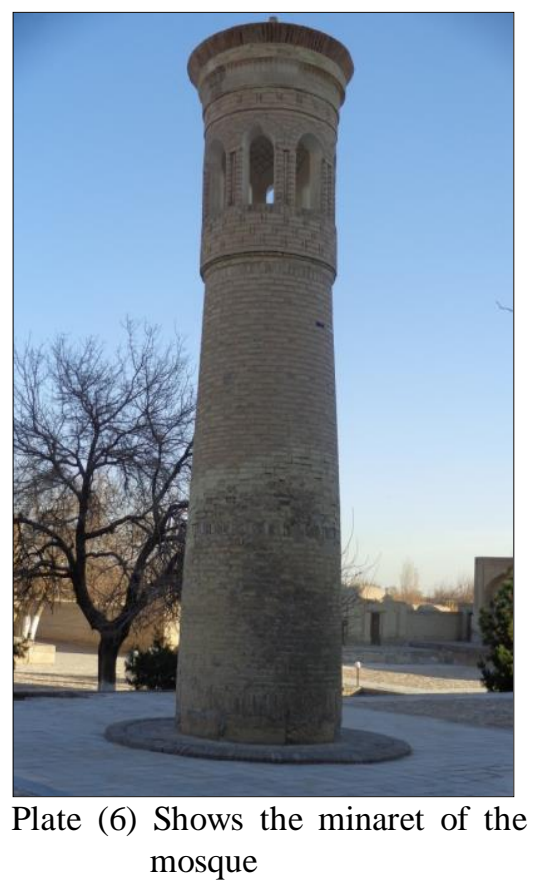


2.2. The khanqah, pl. (7)

It is a square area covered with a shallow dome on spherical triangles, pl. (8). It is located in the Chor Bakr Complex that includes the mosque and the madrasa, as well. The Khanqah' door is in the northern façade. The Khanqah has two iwans only. The main iwan lies on the southwestern and encompasses a mihrab made of bricks with a layer of plaster, pl. (9). Additionally, the inner parts of the stalactite are covered with ceramic tiles and a pentagonal plan. The second iwan lies on the opposite side; the northeastern and encompasses an opening.

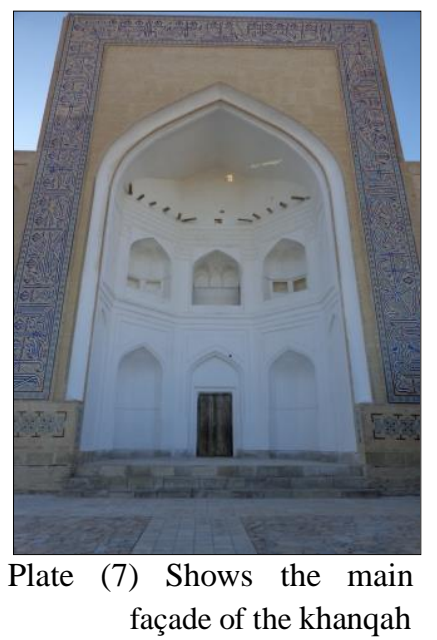

\subsection{The madrasa}

This madrasa, pl. (10) was modeled after the style of one iwan consisting of two floors. Its internal planning consists of a rectangular area including three sides, while the fourth side was fully opened to the outside. In the middle of the madrasa, there is a rectangular court in shape with one iwan to the southwest side surrounded by rooms of students (Khojari). The southeastern and northwestern sides overlook the court through

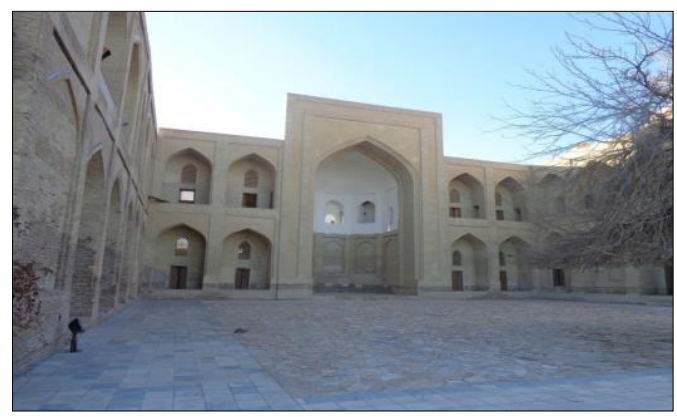

Plate (10) Shows the madrasa of Chor Bakr in Bukhara
The khanqah has a large memorial façade, namely the northeast façade, with a fivefold pointed entrance with pointed arches. It consists of two levels. In the middle of the lower level, there is a door opening with wooden shutters, while the upper level has three windows. Furthermore, the main façades of the mosque and the Khanqah are architectturally symmetric. The entrances have a similar layout, namely pentagram layout. Technically, however, they clearly differ.
Plate (8) Shows the khanqah of Chor Bakr from inside

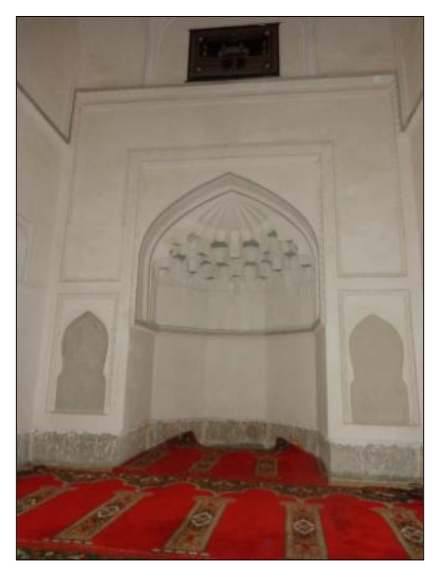

Plate (9) Shows the mihrab of the khanqah of Chor Bakr niches with pointed arches including student rooms on two floors, pl. (11). In Central Asia, the student residence usually overlooks the court through an opening with pointed arch and it is opened to a rectangular area with a rectangular door opening with no arch. Above it, there is a rectangular window with pointed arch covered with emptied stucco. All student rooms are on the second floor opened all to corridors.

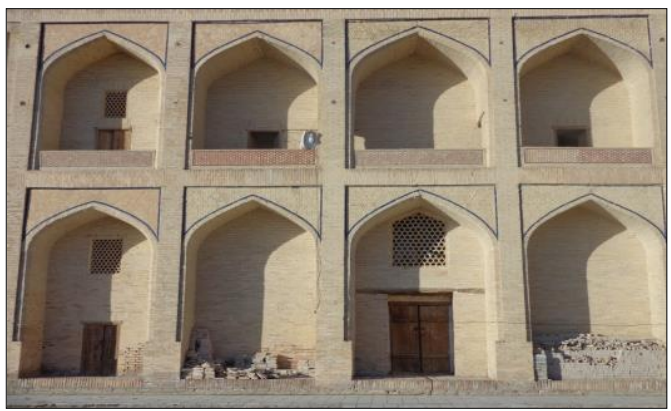

Plate (11) Shows cells of students and the niches overlooking the court in the madrasa of Chor Bakr 


\section{Architectural units}

\subsection{The iwan}

In most buildings of Central Asia, there are openings in the walls of iwans that either lead to the student residence or to classrooms or they are connected to the entrance. These madāris have iwans that vary in number, including two, three, and four. Such iwans are in the middle of the madrasa sides. For example, the main iwan, namely qibla iwan is in the southwestern side, while another iwan lies on the northeastern side. Furthermore, there may be two other iwans in the northwestern and the southeastern sides. The

\subsection{Mihrabs}

The mihrabs of Chor Bakr complex are a continuation of the mihrabs of architectural structures in Central Asia. They are usually five-pointed and a few have a rectangular and semicircular projection like most of the mihrabs of the Eastern Islamic world. Generally, the shape of the mihrab in the period under study was similar to that of the mihrabs in the region in terms of a hollow niche with pointed arch that may directly rely on columns. Sometimes, the mihrabs may be engraved in the wall of the niche. They can be decorated with floral motifs,

\subsection{Student Rooms (Khojari)}

The madrasa comprises a group of student rooms (Khojari), located on either side of the main iwan and on the other sides of the madrasa. The iwans of the Central Asian madāris are opened into the court through an opening with a pointed arch. The second floor opens on a corridor overlooking the court with a handrail. The rooms on the second floor are linked through extended with rectangular openings

\subsection{The court}

The court of Chor Bakr madrasa is open with a rectangular projection and it is surrounded, from three sides, by units while the fourth one is totally open. This court was modeled after the same prevailing type of Central Asian madāris' courts that were wide and brilliant with a rectangular projection that extended from east to west. This width may be due to the nature of Central Asia as the iwans of the Central Asian madāris are opened into the court through an opening with a pointed arch. There are various examples, e.g. the madrasa of abd AlAziz Khan "1062-1063 A.H / 1651-1652 A.D" [9] in Bukhara, the madrasa of Chir Dar "1029-1046 A.H / 1619-1636 A.D" in Samarqand, and the madrasa of Mohamed Amin Khan "1268-1269 A.H / 1852-1853 A.D "in Khiva". Such iwans have higher and wider openings and they are covered with barrel cellars.

geometric shapes, and inscriptions, while others are devoid of decoration. Various examples of such mihrabs in Central Asia may be given, including the mihrabs of Kalan Mosque (6 A.H / 12 A.D), the madrasa of Abdallah Khan (997-990 A.H 1 1588-1590 A.D) 11, Khanqah of Nadir Divan Begi (11A.H / 17 A.D). The mihrabs of Magoki-Attari mosque (6 A.H / 12 A.D), the mosque of Namazgah (6 A.H / 12 A.D), and the mosque of Madri Khan (10 A.H / 16 A.D) [5] are examples of rectangular ribs mihrabs.

in the walls of the arched niches. The madāris of Kukeldash (976-977 A.H / 1568-1569 A.D), Madri Khan (951-954 A.H / 1544-1547 A.D) in Buk-hara, Tela Kari (1057-1071 A.H / 1647-1660 A.D) [10] in Samarqand, and Muha-mmad Amin Khan (1268-1269A.H / 1852-1853 A.D) and Muhammad Rahim Khan (1287 A.H/ 1871 A.D) in Khiva are just examples.

temperature is high in summer. There are various examples of these madāris, e.g. the madāris of Jokshan (1007 A.H / 1598 A.D) [11] in Bukhara, Shir Dar (10291046 A.H / 1619-1636 A.D), Tela Kari (1051-1071 A.H / 1641-1660 A.D) in Samarqand, Kukeldash (976-977 A.H/15681569 A.D) in Tashkent, and Muhammad Amin Khan (1268-1269 A.H / 1852-1853 A.D) in Khiva. 


\subsection{The entrance (The Bech taq)}

The entrance is one of the most important architectural units as it links the interior and exterior parts of the complex, as well as its various units and their outbuildings. Most of the Central Asian buildings comprise one entrance that is the main one overlooking the main street. Such entrance is also luxurious and wide. Additionally, it matches the other architectural units such as the minarets, domes, and iwans. Its layout has a pentagonal projection. The entrances of the madāris of Mir Arab (942-946 A.H / 15351539 A.D) [12] in Bukhara, Buraq Khan (10 A.H / 16 A.D century) [13], and Muhammad Amin Khan (1268-1269 A.H / 1852-1853 A.D) in Khiva are just examples.

\subsection{The minarets and towers (goldasta)}

The minarets of Chor Bakr complex was modeled after the same model that prevailed in Central Asia. A minaret has a horizontal circular projection. It is cylindrical and becomes narrower as it moves up and it is crowned with rows

\subsection{The domes (Gombaz)}

They were modeled after the domes of Samarqand that were high with long drums; their diameter was smaller than that of the body itself. The circle of the dome is inside-out beginning from the arch of the window on a large area of the lintel of the window to release the pressure. Thus, they were doubled domes, i.e. an

of stalactites, ending with a jawsaq of pointed arches; the shape of Central Asian skull caps. Sometimes, it was separated from the building, e.g. the mosque of Labi Hauz [14] in Bukhara.

inner semicircular dome and an outer pointed one, such as the domes of the madrasa of Mir Arab (942-946 A.H / 15351539 A.D) in Bukhara, the tomb dome of Toman Aqa (808 A.H / 1405 A.D) in Samarqand, and the madrasa of Buraq Khan (10 A.H / 16 A.D century) in Tashkent.

\section{Discussion}

The mosque, khanqah, and madrasa have a pi-shaped layout. This ensemble is unusual. Their original layout adopted the traditional Muslim construction, which testifies to the active creative search of Bukhara architects. The façades of the khanqah and the mosque are distinguished with the identical portals, but their layout and volumetric-spatial construction differ. The ensemble had an influence on the

further extension of the Chor Bakr memorial. Furthermore, the construction of the mosque and khanqah has original models of the intersecting arches, a network of the intermediate shield-shaped pendentives and stalactites. The exterior decoration consists of glazed bricks and majolica ornament. The construction system itself creates the common effect inside.

\section{Conclusion}

After studying the complex of Chor Bakr, the following results are concluded: 1- The complex of Chor bakr is characterized by symmetry; its three buildings were arranged on one berth in the form of the Russian alphabet (II), and it is considered a memorial building. 2- The mosque of the complex follows the plan of closed mosques that include a court. Thus, it follows the second style of the mosques of Central Asia. 3- The mosque and khanqah have a large dome covering the central part based on Turkish triangles and carrying the helmet of the dome with long drum known by Samarqandi domes. 4- The madrasa consists of three sides only; the southwestern, southeastern, and northwestern, while the fourth side is open outside with no architectural elements. 5- The madrasa belongs to the style of one iwan including two floors similar to the madrasa of Joibari Kalan in Bukhara. 6- The units of the madrasa do not open into the court directly, but into the arched niches that open into the court. The second floor opens into a corridor overlooking the court through a handrail. 7- The main façades of the mosque and the khanqah are higher than the others that characterize Central Asia. 8- The 
minaret is established outside the mosque at the northern corner of the main façade (northeastern) $15 \mathrm{~m}$ away, such as in the mosque of Kalan and the mosque of Labi Houz in Bukhara. 9- The minaret of the complex is a cylindrical building of bricks. Its diameter decreases then it becomes wider, including the decorations executed in bricks. 10- The mihrabs of the complex adopt the prevailing of styles; they are rectangular in the mosque and pentagonal in the khanqah.

\section{References}

[1] Arapov, A., (2011). Historical monument of Uzbekistan (Tashkant, Samarkand, Bukhara, Khiva, Shahrisabz), Univ. of Orientalism, Tashkant.

[2] De George, G., \& Porter, Y., (2002). The art of Islamic tile, Flammarion, Paris.

[3] Husenov, P., \& Razhabov, A., (2002). Чор Бакр (Alabkar Alarbaa), Institute of Architecture, Tashkant.

[4] Muini, R., (2007). Памятники Аpхитектуры в Бухаре (Al Athar Al memaria in Bukhara), Institute of Al-Biruni, Tashkent.

[5] Arapov, A., (2006). Bukhara, masterpieces of central Asia, Institute of Architecture, Tashkent.

[6] Brokhaza, A., (1993). Architecture of Islamic civilization in Bukhara, Khwarizm, Organization of Islamic capitals and cities, Macca.

[7] Zohidov, N., (1996). Архитектурная жизнь (Alhiah Al meemaria), Univ. of Orientalism, Tashkent.

[8] Ragab, A., (2017). Al ather wa al thkafa al Islamia fi Bukhara (Islamic archaeology \& culture in Bukhara), Vol

1, Kuwait Center for Islamic Arts, Kuwait.

[9] Blair, A., \& Jonathan, M., (1990). The art and architecture of Islam, American Univ. of Sharjah, UAE.

[10] Ebaid, Sh., (2012). Diwan Al khat Al arbi fi Samarkand (Divan of Arab Calligraphy in Samarkand), Bibliotheca Alexandria, Egypt.

[11] Pugachenkova, G., (1983). Средняя Азия (Asia Al wosta), Institute of Architecture, Tashkent.

[12] Smith, H., (1982). Bukhara, Progress Pub., Moscow.

[13] Retviladzi, L., (1995 Исламские памятники в Узбекистане (Al-asar El-eslamiya fi Uzbekistan), Institute of Al-Biruni, Tashkent.

[14] Pugachenkova, G., (1981). A museum in the open. the architectural treaures of Uzbekistan, Edité par Gafur Gulyam Art \& Literature Publishing House, Tashkent. 